\title{
Evaluation of Nurse Managers' Use of Employee Empowerment as Motivator to their Subordinate at Enugu State University of Science and Technology Teaching Hospital, Enugu
}

\author{
Ude CC ${ }^{1}$, Nwaneri $\mathrm{AC}^{2}$, Ezenduka $\mathrm{PN}^{3}$, Okorokwo $\mathrm{I}^{2}$ and $\mathrm{Ndie}^{\mathrm{E}} \mathrm{C}^{4}$
}

${ }^{1}$ School of Nursing, ESUT Teaching Hospital, Enugu, Nigeria

${ }^{2}$ Department of Nursing Science, University of Nigeria, Enugu campus, Nigeria

${ }^{3}$ Department of Nursing Science, Nnamdi Azikiwe University, Nnewi Campus, Nigeria

${ }^{4}$ Department of Nursing Science Ebonyi State University Abakaliki, Nigeria

\begin{abstract}
The study aimed at identifying how nurses perceive the use of employee empowerment strategy by their managers as a motivator to their subordinates at Enugu State University of Science and Technology Teaching Hospital, Enugu. Descriptive survey research design was used. Questionnaire was used as instrument of data collection. 235 nurses participated in the study. $100(42.6 \%)$ respondents said subordinates are sometimes giving recommendation 92 $(39.1 \%)$ respondents said subordinate are never allowed to further their study, with Mean $3 \pm P$. value $=0.000$.

The findings showed that nurse managers do not use employee empowerment as strategy for motivating nurses under them. It was recommended that educational programmes be organized for nurses to enable them to understand the use of employee empowerment as strategies for staff motivation.
\end{abstract}

Keywords: Nurse manager; Employee empowerment; Motivator; Subordinate

\section{Introduction}

Motivation is one of the key ways of increasing productivity. The act of motivating employee is complex because what motivate employees changes constantly and varies from individual to individual. Utilization of motivational strategies as perceived by nurses is associated with rationing of staff, positive attitude to work, reduced absenteeism, commitment to work, reduced mortality rate of patients and achievement of set goals [1].

According to Michigan Conversation Guide (2004) empowerment is the process of enabling or authorizing an individual to think, behave, take action and control work and decision making in autonomous ways [2]. Employee empowerment means making employee involved in their job and in the operation of the organization by increasing their participation in the decision making. The company's management style involves sharing employee's expectations and framework with the employee and getting out of the way while employees were empowered to set goals, accomplish objective and determine how to do their job. Empowerment means making employees more involved in their jobs and in the operations of the organization, by increasing their participation in decision making. Empowered employees have voice in what they do, and how and when they do it [3].

Ishmael noted that motivated employees always look for better ways to do a job and are of more quality. Motivated workers render their best services effectively and efficiently thereby increasing productivity [4]. Other benefits include reduction in absenteeism, migration and negative attitude to work such as lateness. On the contrary, when workers are not motivated, the consequences include absenteeism, lateness to work, negative attitude to work place especially towards the recipients of services, high migration rate, indifference to work [5].

This study is aimed at examining the perception of nurses on the use of employee empowerment as a motivational strategy by nurse managers in Enugu State University of Science and Technology Teaching Hospital, Enugu.

\section{Methodology}

A non-experimental descriptive survey research was used to study of use of employee empowerment as motivational strategies by nurse managers at ESUTH Enugu as perceived by their subordinates. 235 nurses out of 253 nurses, on duty at the time of study and who were willing to participate in the study were used. The instrument used for the study was questionnaire constructed by the researchers on employee empowerment strategies. A pilot study was conducted at UNTH Enugu using the instrument. The internal consistency of the instrument using the Cronoch's alpha co-efficient test was 0.716 . Permission was obtained from ESUTH management and individual respondent gave personal consents. The questionnaire was distributed to the nurses as they report on duty and collected back before their duty were over that same day. The data were collected and analyzed using SPSS version 18 .

\section{Results}

Table 1 showed mean, standard deviation and percentage responses on the perception of nurses on nurse managers' use of employee empowerment in staff management as well as the p-value.

In determining the nurses perception of their managers' use of employee empowerment, $19(8.1 \%)$ respondents said that subordinates are always recommended by managers to further their study. 24 (10.27) respondents said subordinates are often recommended by managers

*Corresponding author: Elke Ndie, Department of Nursing Science, University of Nigeria, Enugu campus, Nigeria, Tel: 07066789961; 08077506819; E-mail: chubike05@yahoo.com

Received July 29, 2017; Accepted August 23, 2017; Published August 30, 2017

Citation: Ude CC, Nwaneri AC, Ezenduka PN, Okorokwo I, Ndie EC (2017) Evaluation of Nurse Managers' Use of Employee Empowerment as Motivator to their Subordinate at Enugu State University of Science and Technology Teaching Hospital, Enugu. J Pat Care 3: 132. doi: 10.4172/2573-4598.1000132

Copyright: ( 2017 Ude CC, et al. This is an open-access article distributed under the terms of the Creative Commons Attribution License, which permits unrestricted use, distribution, and reproduction in any medium, provided the original author and source are credited. 
Citation: Ude CC, Nwaneri AC, Ezenduka PN, Okorokwo I, Ndie EC (2017) Evaluation of Nurse Managers' Use of Employee Empowerment as Motivator to their Subordinate at Enugu State University of Science and Technology Teaching Hospital, Enugu. J Pat Care 3: 132. doi: $10.4172 / 2573-4598.1000132$

Page 2 of 3

\begin{tabular}{|c|c|c|c|c|c|c|c|c|}
\hline \multirow{2}{*}{ S. No. } & \multirow{2}{*}{$\begin{array}{l}\text { Response to nurse } \\
\text { Managers use of Employee empowerment }\end{array}$} & \multirow{2}{*}{$\begin{array}{l}\text { Always } \\
F(\%)\end{array}$} & \multirow{2}{*}{$\begin{array}{l}\text { Often } \\
F(\%)\end{array}$} & \multirow{2}{*}{\begin{tabular}{|c|} 
Sometimes \\
$F(\%)$
\end{tabular}} & \multirow{2}{*}{$\begin{array}{l}\text { Never } \\
F(\%)\end{array}$} & \multirow{2}{*}{$\begin{array}{l}\text { Total } \\
\text { F (\%) }\end{array}$} & \multicolumn{2}{|c|}{ Mean P-Value } \\
\hline & & & & & & & $F(\%)$ & (SD) \\
\hline 1 & Subordinates are recommended by managers to further their study & $19(8.1)$ & $24(10.2)$ & $100(42.6)$ & $92(39.1)$ & $235(100.0)$ & $3(0.9)$ & 0.000 \\
\hline 2 & Nurses have impact on decision and actions concerning their job. & $22(9.4)$ & $35(14.9)$ & $32(13.6)$ & $146(62.1)$ & $235(100.0)$ & $3(1)$ & 0.000 \\
\hline 3 & Nurses enjoy healthy working Environment through effective & 27 (11.5) & $26(11.1)$ & $51(21.7)$ & $131(55.7)$ & $235(100.0)$ & $3(1)$ & 0.000 \\
\hline 4 & Nurses are allowed to have access to the locked-up resources & $33(14.0)$ & $22(9.4)$ & $55(23.4)$ & $125(53.2)$ & $235(100.0)$ & $3(1.1)$ & 0.000 \\
\hline 5 & Managers run periodic evaluation of subordinates on & $20(8.5)$ & $20(15.3)$ & $48(54.0)$ & $144(22.1)$ & $235(100.0)$ & $3(0.8)$ & 0.000 \\
\hline 6 & $\begin{array}{l}\text { Nurses are allowed to initiate and implement positive actions in their units } \\
\text { when the manager is not allowed }\end{array}$ & $24(10.2)$ & $37(15.7)$ & $108(46.0)$ & $66(28.1)$ & $235(100.0)$ & $3(0.9)$ & 0.000 \\
\hline
\end{tabular}

Overall Mean=3; P-value=0.000, SD=0.9; $n=235$

Table 1: Responses on use of employee empowerment as a motivation strategy by managers.

to further their study. $100(42.6 \%)$ respondents said subordinates are sometimes giving recommendation $92(39.1 \%)$ respondents said subordinate are never allowed to further their study, with Mean $3 \pm \mathrm{P}$. value $=0.000$.

Concerning having impact on decision 22 (9.4\%) respondents said nurses always have impact on decision and actions that affect their job, 35 (14.9\%) respondents said nurses often have impact. 32 (13.6\%) respondents said nurses sometimes have impact on decision and actions that affect their job; while $146(62.1 \%)$ respondents said nurses never have impact on decisions and actions that affect their job. Mean $3 \pm 1 \mathrm{P}$. value $=0.000$.

On whether nurses enjoy healthy environment 27 (11.5\%) respondents said nurses always enjoy healthy working experience through effective communication. $26(11.1 \%)$ respondents said nurses often did 57 (21.7\%) respondents said nurses sometimes enjoy healthy working environment through effective communication; while 131 (55.7\%) respondents said nurses never enjoy healthy working environment through effective communication from managers with Mean $3 \pm 1=\mathrm{P}$. value 0.000 .

On the issue of whether subordinates are allowed to have access to stores, $33(14.0 \%)$ respondents said nurses are always allowed to have access to the locked up stores when managers are not there. 22 (9.4\%) respondents said nurses are often allowed to have access to 55 (23.4\%) respondents said nurses are sometimes allowed to have access to the locked up stores in absence of the manager; while 125 (53.2\%) respondents said nurses are never allowed to have to locked up stores when the manager is not there with Mean $3 \pm 1.1 \mathrm{P}$. value $=0.000$.

Concerning whether nurses are allowed to control financial resources, $23(9.8 \%)$ respondents said nurses are always allowed to control financial resources needed. $20(8.5 \%)$ respondents said nurses are often allowed control. 48 (20.4\%) respondents said nurses are sometimes allowed to have control of financial resources needed in the unit, while $144(61.3 \%)$ respondents said nurses are never allowed to have control, with Mean $3 \pm 1$, P. value 0.000 .

This finding implies that managers are not using the motivation strategy in staff management. On issue of managers run periodic evaluation, $20(8.5 \%)$ respondents said managers always run periodic evaluation of subordinate on their job performance. $36(15.3 \%)$ respondents said managers did that often. 127 (54.0\%) respondents said managers sometimes run this, while $52(22.1 \%)$ respondents said managers never run periodic evaluation to subordinate on their job performance, with Mean $3 \pm 0.8$ P. value $=0.000$.

Whether nurses are allowed to implement positive action, 24 (10.2\%) respondents said nurses are always allowed to initiate and implement positive actions when managers is not around, while 66
(28.1\%) respondents said nurses are never allowed to initiate and implement positive action, with Mean $3 \pm 0.9$, P. value 0.000 .

\section{Discussion}

Study findings show that higher percentage of nurse employees perceived themselves as not given empowered by their nurse managers. Nurses like any other employees enjoy work environment that allowed access to the locked-up resources when the managers are not there, control financial resources needed for in unit [5]. This finding when viewed in line with Dunn must likely affecting the input these nurses in their work place resulting to absenteeism, and customer dissatisfaction. This observation is also supported by Cortez and Chapex who perceived employee empowerment in staff management a strong tool in creating and sustaining a work environment that facilitates the employee's choice to invest in and own personal action and behavior resulting in positive contributions to the organization's mission [6]. On the same note, Pussil and Kimie has emphasized that unavailability of employee empowerment as found in this study, limit nurses capacity to work properly [7]. Besides, it could create problem among nurses and between nurses and other members of health team. For example, a doctor who is going on ward round could request for hand gloves or catheter for examination of patient and if the subordinates cannot make it available because the nurse manager locked her office, there could be conflict between nurse and doctor and at the end, patient may likely suffer it. It could also negatively affect patients' perception of nurses as incompetent [8].

\section{Conclusion}

It was concluded from the study that majority of the nurses perceived that their managers do not consistently utilize employee empowerment in staff management. Nurses do not have impact on decision and action that affect their job. Nurses are not allowed to have locked-up resources when managers are not there. Nurses are not allowed to control financial resources.

\section{Recommendation}

The following recommendations were made that Nurse Managers should involve subordinates in goal setting and decision making and also communicate vital information/management decisions that are personal or work related. Nurse Managers should encourage team work with their subordinates so as to have adequate understanding of individual need or expectations from their work. Nurse Managers should assign responsibilities to subordinates, supervise and make objective corrections where necessary.

\section{References}

1. Kapor (2010) Job empowerment.

2. (2004) Michigan Conversation Guide. Journal of Motivational studies 79: 1-5. 
Citation: Ude CC, Nwaneri AC, Ezenduka PN, Okorokwo I, Ndie EC (2017) Evaluation of Nurse Managers' Use of Employee Empowerment as Motivator to their Subordinate at Enugu State University of Science and Technology Teaching Hospital, Enugu. J Pat Care 3: 132. doi: $10.4172 / 2573-4598.1000132$

3. World Health Organization (2006) Taking stock, health workers shortage and their response to AIDS.

4. Mbindyo PM, Blaauw D, Gilson L, English M (2009) Developing a tool to measure to health workers motivation in district hospital Kenya. Human Resources for Health 7: 19.

5. Dovlo D (2005) Wastage in the health workforce, some perceptive from African countries. Human Resources for Health 3: 9.
6. Corte B, Lopex S (2009) A practical guide for motivation in work place. Jersye Publisher, USA.

7. Pusil S, Kinnie L ( 2007) The potential impact of job satisfaction on staff management, p: 10.

8. Schell BA Slater DY (1998) Management competencies required of administrative and clinical practitioners in the new millennium. Am J Occup Ther 52:744-750. 